\title{
Characterization of non-equilibrium and equilibrium occurrences of paragonite/muscovite intergrowths in an eclogite from the Sesia-Lanzo Zone (Western Alps, Italy)
}

Received: 3 February 1999 / Accepted: 19 October 1999

\begin{abstract}
Coexisting muscovite and paragonite have been observed in an eclogite from the Sesia-Lanzo Zone (Western Alps, Italy). The $P-T$ conditions of this eclogite reached $570-650{ }^{\circ} \mathrm{C}$ and $19-21 \mathrm{kbar}$ and the rocks show several stages of mineral growth during their retrograde path, ranging from the subsequent lower- $P$ eclogite facies to the blueschist facies and then the greenschist facies. Muscovite and paragonite are very common in these rocks and show two texturally different occurrences indicating equilibrium and non-equilibrium states between them. In one mode of occurrence they coexist in equilibrium in the lower- $P$ eclogite facies. In the same rock muscovite \pm albite also replaced paragonite during a greenschist-facies overprint, as evidenced by unique across - (001) layer boundaries. The chemical compositions of the lower- $P$ eclogite-facies micas plot astride the muscovite - paragonite solvus, whereas the compositions of the greenschist-facies micas lie outside the solvus and indicate disequilibrium. The TEM observations of the textural relations of the greenschist-facies micas imply structural coherency between paragonite and muscovite along the layers, but there is a sharp discontinuity in the composition of the octahedral and tetrahedral sheets across the phase boundary. We propose that muscovite formed through a dissolution and recrystallization process, since no gradual variations toward the muscovite - paragonite interfaces occur and no intermediate, homogeneous $\mathrm{Na}-\mathrm{K}$ phase has been
\end{abstract}

\footnotetext{
G. Giorgetti $(\bowtie)^{1}$

Department of Geological Sciences, The University of Siena, Via Laterina, 8; I-53100 Siena, Italy

Tel.: ++ 39-0577-263830; Fax: ++39-0577-263938

e-mail: giorgett@dst.unisi.it
}

G. Giorgetti · P. Tropper · E.J. Essene · D.R. Peacor Department of Geological Sciences, University of Michigan, Ann Arbor MI 48109-1063, USA

Present address:

${ }^{1}$ Dipartimento di Scienze della Terra, via Laterina 8

53100 Siena, Italy

Editorial responsibility: T.L. Grove observed. Because a solid-state diffusion mechanism is highly unlikely at these low temperatures $\left(300-500{ }^{\circ} \mathrm{C}\right)$, especially with respect to octahedral and tetrahedral sites, it is assumed that $\mathrm{H}_{2} \mathrm{O}$ plays an important role in this process. The across-layer boundaries are inferred to be characteristic of such non-equilibrium replacement processes. The characterization of these intergrowths is crucial to avoiding erroneous assumptions regarding composition and therefore about the state of equilibrium between both micas, which in turn may lead to misinterpretations of thermometric results.

\section{Introduction}

Observations of metamorphic assemblages and experimental studies on white micas indicate the presence of a wide solvus between muscovite and paragonite (Eugster and Yoder 1955; Zen and Albee 1964; Eugster et al. 1972; Chatterjee and Flux 1986; Flux and Chatterjee 1986; Roux and Hovis 1996). The degree of Na substitution in muscovite coexisting with paragonite, and $\mathrm{K}$ in paragonite, mutually increases with increasing temperature, providing a potentially powerful thermometer (Rosenfeld et al. 1958; Blencoe et al. 1994). However, the fundamental assumption that allows estimates of intensive variables from mineral assemblages is that the mineral phases attained a state of equilibrium at some pressure and temperature conditions. Mineralogical, textural, and chemical heterogeneities usually reflect a lack of equilibrium, which is a common feature in polymetamorphic rocks (Essene 1982). Identification of textural equilibrium is very important for sheet silicates, since they commonly occur as fine-grained intergrowths (Shau et al. 1991; Giorgetti et al. 1997) or mixed layering (Frey 1969; Li et al. 1994b) at scales below electron microprobe resolution.

Coexisting Na-K white micas have been described from low- to medium-grade metamorphic rocks throughout the world and they are widespread in blueschist- and eclogite-facies assemblages (Guidotti 1984; 
Ahn et al. 1985 and references therein; Droop et al. 1990; Mottana et al. 1990; Shau et al. 1991; Guidotti et al. 1994 and references therein). Ahn et al. (1985) showed phengite lamellae submicroscopically intergrown in paragonite and warned of interpreting chemical analyses of white micas without proper characterization. The same conclusion has been drawn by other authors (Shau et al. 1991; Jiang and Peacor 1993; Boundy et al. 1997) who analyzed white micas with high-resolution techniques. The possibility of exsolution lamellae (Livi et al. 1988), of other submicroscopic intergrowths (Shau et al. 1991), and of a metastable, intermediate Na-K mica-like sheet silicate precursor (bramallite, Jiang and Peacor 1993) have been documented. Consequently, textural and chemical features must accurately be investigated in order to understand the relationships between white micas in a metamorphic assemblage.

In this paper we describe coexisting muscovite and paragonite from an eclogite in the Sesia-Lanzo Zone, where equilibrium and disequilibrium growth of the micas occurs. It is evident from the petrographic characterization of this eclogite that several different mineral assemblages formed at various $P$ - $T$ stages during its metamorphic evolution (Armando 1992; Tropper 1998). Muscovite and paragonite coexist in equilibrium in the lower- $P$ stages of eclogite-facies metamorphism, and paragonite was partially replaced by muscovite during the subsequent greenschist-facies overprint on the ret- rograde path. In this paper, we compare back-scattered electron (BSE) observations and electron microprobe data with transmission and analytical electron microscopy (TEM - AEM). The purpose is to investigate the nature and origin of paragonite and muscovite occurrences and to determine their chemical compositions and structural relations in order to obtain information about the attainment of equilibrium between the two micas.

\section{Geological overview}

The Sesia-Lanzo Zone is one of the internal Austroalpine units of the Western Alps in northern Italy (Dal Piaz et al. 1972; Compagnoni et al. 1977; Droop et al. 1990) (Fig. 1). Based on comprehensive petrographic and structural investigations, it is subdivided into three main complexes (Venturini et al. 1994, 1995): (1) The Polymetamorphic Basement Complex; (2) the Monometamorphic Cover Sequences; (3) the Pre-Alpine Basement Complex ("Seconda Zona Dioritica Kinzigitica" or IIDK). The Polymetamorphic Basement Complex contains three units with different Alpine

Fig. 1 Geological overview of the Sesia-Lanzo Zone based on Venturini et al. (1994). The interpretative geological inset map of the area around Mt. Mucrone is based on the MS thesis of Armando (1992). The samples were collected from the metagranulites and metaamphibolites along the Ianca River (no period)

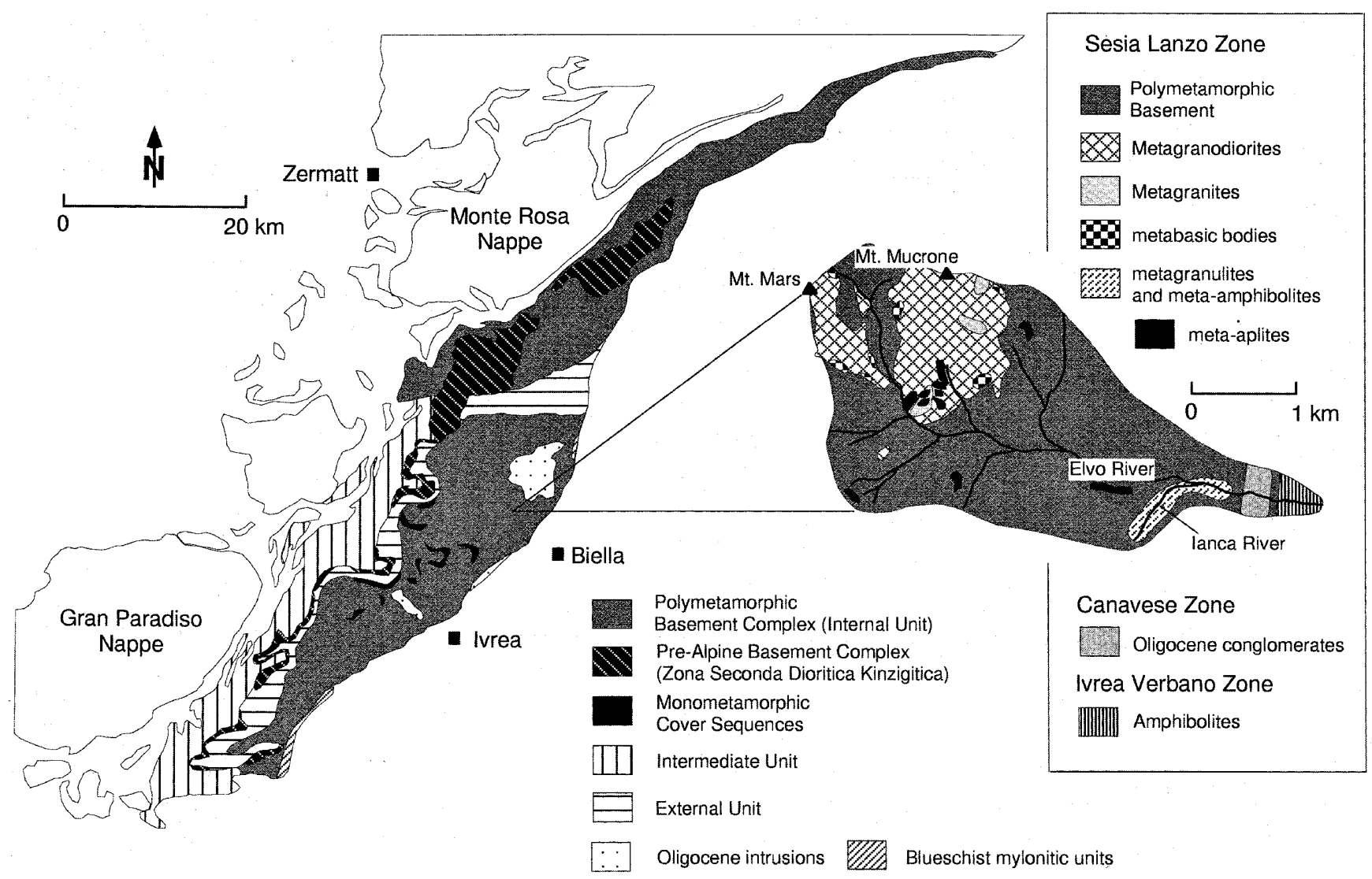


metamorphic characteristics (Paschier et al. 1981). The Internal Unit, formerly known as the "Eclogitic Micaschist Unit" in the east, equilibrated under Eo-Alpine eclogite-facies conditions and shows only minor greenschist-facies overprint. Toward the west, the Intermediate Unit with an increasingly developed greenschist-facies overprint is followed by the External Unit, which is almost completely overprinted by greenschist facies. These two units were formerly known as the Gneiss Minuti Unit (Compagnoni et al. 1977). The Monometamorphic Cover Complex contains Triassic metabasalts and terrigenous sequences and crops out as a continuous belt in the central and southern Sesia Zone. The Pre-Alpine high-temperature Basement Complex ("Seconda Zona Dioritica Kinzigitica" or IIDK) is scattered throughout the Sesia-Lanzo Zone and contains Hercynian high-temperature basement rocks (Dal Piaz et al. 1972). The samples under investigation are eclogites, which were collected along a ca. $400 \mathrm{~m}$ traverse from the Ianca River, $10 \mathrm{~km}$ west of Biella in northern Italy. These outcrops occur in the easternmost part of the Polymetamorphic Basement Unit near the Canavese Zone, as shown in the interpretative geological inset map in Fig. 1, based on detailed field work by Armando (1992).

\section{Textural relations and petrography}

The rocks under study were mapped as metagranulites and meta-amphibolites and were fully equilibrated under Eo-Alpine metamorphic conditions (Armando 1992; Tropper 1998). The pre-Alpine assemblage is completely replaced by high-pressure assemblages. The rocks display several stages of mineral growth and extensive retrogression which led to the formation of subsequent lower- $P$ eclogite-, blueschist- and greenschist-facies assemblages after the high-pressure peak assemblage. The earliest mineral assemblage paragonite + clinozoisite + zoisite + kyanite + quartz is preserved in the cores of garnet porphyroblasts. It is inferred to have formed before the high-pressure event. The peak highpressure assemblage in the eclogites is preserved only as inclusions in the rims of garnet porphyroblasts containing the assemblage omphacite + clinozoisite \pm zoisite + kyanite + quartz + rutile. The matrix in the eclogites contains several different mineral assemblages, which are related to the retrogression and are listed below:

1. Lower- $P$-eclogite facies: This facies contains garnet + barroisite + omphacite + clinozoisite \pm zoisite + quartz + rutile \pm dolomite \pm paragonite \pm muscovite but no kyanite. In this stage, muscovite and paragonite coexist (Fig. 2).

2. Blueschist facies: Glaucophane appears in this facies together with clinozoisite + zoisite + paragonite + quartz. Glaucophane usually forms rims around bar-



Fig. 2 Back-scattered image of coexisting muscovite and paragonite from the lower- $P$ eclogite-facies assemblage (muscovite $M s$, paragonite $P g$, omphacite $O m p$, clinozoisite $C z o$ ); (sample IBSF 40); the scale bar is $10 \mu \mathrm{m}$

roisite and sometimes omphacite. On the basis of textures, it is not clear whether muscovite and paragonite coexist.

3. Greenschist facies: The greenschist facies is marked by the assemblage actinolite \pm clinozoisite + chlorite + muscovite + albite \pm calcite \pm talc \pm titanite (Fig. 3). Muscovite pervasively overgrows paragonite, and both micas form complex intergrowths (Fig. 4a, b). The muscovite - paragonite boundaries are mostly oblique with respect to the mica cleavage planes, which appear to be continuous across the boundaries (Fig. 4a, b).

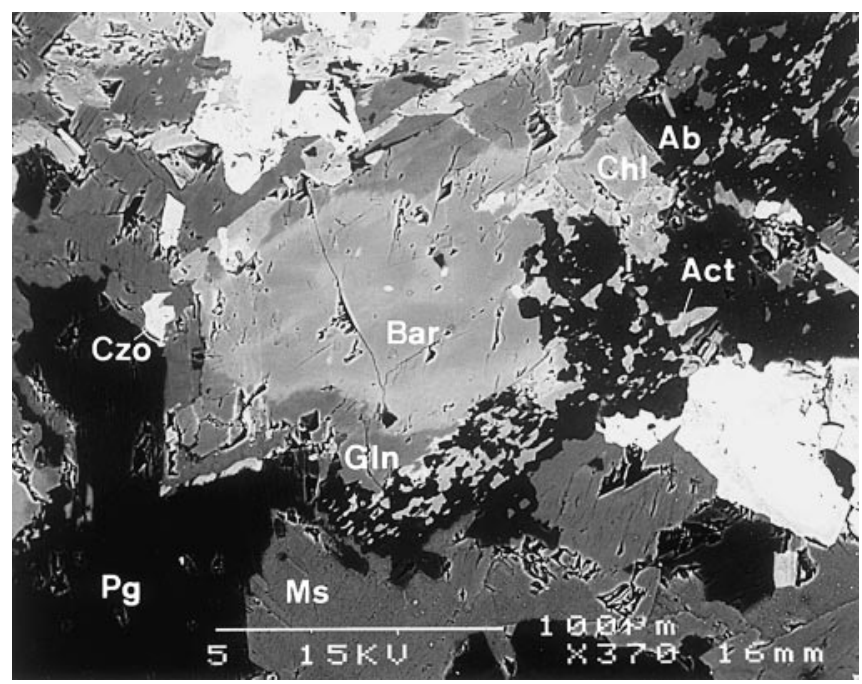

Fig. 3 Back-scattered image of the greenschist-facies assemblage replacing glaucophane $(G l n)$, barroisite $($ Barr $)$ and paragonite $(P g)$ from high-pressure stages (muscovite $\mathrm{Ms}$, chlorite $\mathrm{Chl}$, actinolite $\mathrm{Act}$, albite $A b$ ). The white grains are clinozoisite ( $C z o$ ); (sample IBSF 10); the scale bar is $100 \mu \mathrm{m}$ 

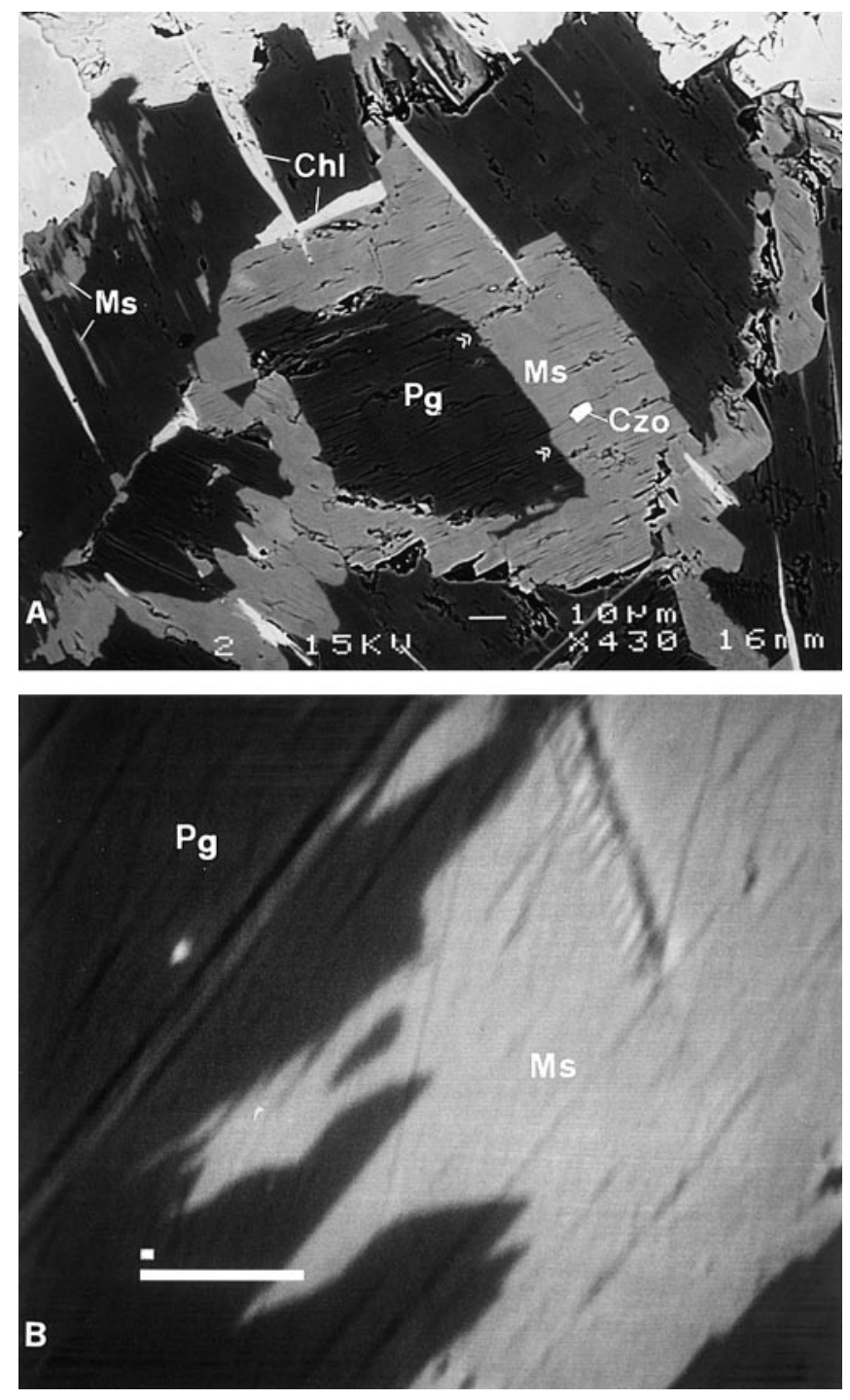

Fig. 4 A,B Back-scattered image, showing the textural relationship between muscovite and paragonite in the greenschist facies. A Muscovite replaces a lower- $P$ eclogite-facies paragonite porphyroblast; the arrows show where across-layer transformation of paragonite to muscovite took place; the paragonite $(P g)$-muscovite $(M S)$ boundaries are oblique with respect to (001) layers. The white mineral is clinozoisite $(\mathrm{Czo})$. B Detail from a muscovite - paragonite intergrowth (sample IBSF 10); the scale bar in both images is $10 \mu \mathrm{m}$

\section{Thermobarometry}

Thermobarometry was performed by calculating phase equilibria among the coexisting phases in the NCMASH system from each stage of mineral growth by selecting appropriate activity models for the phases of interest, with the database of Holland and Powell (1990) and their updated version of the program THERMOCALC v 2.4 (Holland written communication 1995). The calculations yielded invariant points which were used to estimate $P, T$ conditions and $a_{\left(\mathrm{H}_{2} \mathrm{O}\right)}$. The $\mathrm{Fe}^{2+}-\mathrm{Mg}$ exchange thermometry between garnet and omphacite (Krogh 1988) and garnet and hornblende (Graham and Powell 1984) was also used. The detailed thermobarometric evaluation of these rocks is beyond the scope of this paper (see Tropper 1998 for further details). His calculations yield a $P-T$ peak of 19-21 kbar and $570-650{ }^{\circ} \mathrm{C}$ for the high-pressure peak. The conditions of the subsequent retrograde path are estimated to be
500-600 ${ }^{\circ} \mathrm{C}$ and $16-19$ kbar for the the lower- $P$ stage eclogitefacies assemblage, $450-550{ }^{\circ} \mathrm{C}$ and $9-13 \mathrm{kbar}$ for the blueschist-facies assemblage and $300-500{ }^{\circ} \mathrm{C}$ and $4-7 \mathrm{kbar}$ for the greenschist-facies assemblage (Tropper 1998). During the $P-T$ peak and the retrograde path, $a_{\left(\mathrm{H}_{2} \mathrm{O}\right)}$ remained high (0.85-0.99). The estimates of the $P-T$ path are generally in agreement with those derived from other eclogites in the Sesia-Lanzo Zone (Reinsch (1979), Lardeaux et al. (1982), Rubie (1984), Morten (1993 and references therein), Venturini (1995).

\section{Analytical methods}

Microprobe analyses of the minerals were obtained using a CAMECA CAMEBAX microprobe with four WDS (wavelength dispersive) spectrometers at the University of Michigan. The microprobe was operated at $15 \mathrm{kV}$ and $10 \mathrm{nA}$ beam current. A rastered beam with a diameter of $3 \times 3 \mu \mathrm{m}$ was used to minimize volatilization. Natural and synthetic phases were used as standards, including Tiburon albite (Na), Gotthard adularia (K), New Idria jadeite $(\mathrm{Na})$, natural diopside $(\mathrm{Si})$, Broken Hill rhodonite $(\mathrm{Mn})$, synthetic uvarovite $(\mathrm{Cr})$, Ingamells almandine $(\mathrm{Fe}, \mathrm{Al})$, synthetic geikielite (Ti), Marjalahti olivine $(\mathrm{Mg})$, natural sanbornite $(\mathrm{Ba})$, Topaz Mts. topaz $(\mathrm{F})$, synthetic $\mathrm{Ba}-\mathrm{Cl}$ apatite $(\mathrm{Cl})$ and Willsboro wollastonite $(\mathrm{Ca})$. The raw data were reduced with a PAP-type correction and software provided by Cameca. The stoichiometric mineral formulae were calculated using the program MINFILE (Afifi and Essene 1988). Back-scattered electron (BSE) images were obtained on polished thin sections using a HITACHI S-3200 N, scanning electron microscope (SEM) equipped with a Noran X-ray energy-dispersive system operated at $20 \mathrm{kV}$ at the University of Michigan and a GEOL SEM 6310 scanning electron microscope equipped with a LINK ISIS energy-dispersive system operated at $15 \mathrm{kV}$ at the Karl-Franzens Universität Graz, Austria.

Following optical and BSE imaging, ion-milled TEM specimens were prepared following the methods of Li et al. (1994a). The TEM observations and AEM analyses were obtained using a Philips CM12 scanning transmission electron microscope (STEM), operated at an accelerating voltage of $120 \mathrm{kV}$ and beam current of $\sim 10 \mu \mathrm{A}$. Lattice-fringe images were obtained using 001 reflections (Li et al. 1994a). The X-ray energy-dispersive spectra were obtained using a Kevex Quantum detector. A raster of $200 \times 200 \mathrm{~nm}$ (as maximum size) in scanning mode was used to minimize alkali diffusion and volatilization. The AEM spectra were processed using $\mathrm{k}$-values from ion-milled standards of paragonite, muscovite, albite, clinochlore, fayalite, rhodonite, and titanite as described by $\mathrm{Li}$ et al. (1994a) with formulae normalized to a sum of twelve octahedral and tetrahedral cations.

\section{Chemical data}

Representative electron microprobe analyses of muscovite, paragonite and greenschist-facies albite are shown in Table 1 . The $\mathrm{K}$ content $[\mathrm{K} /(\mathrm{K}+\mathrm{Na}+\mathrm{Ca})]$ of the lower- $P$ eclogite-facies paragonite porphyroblasts ranges from 0.07-0.12. Phengitic muscovite [Si 6.4-6.6 pfu (per formula unit)] coexists with paragonite in sample IBSF 4 within the lower- $P$ eclogite-facies assemblage clinozoisite + zoisite + omphacite, but in most cases muscovite occurs only as part of the greenschist facies. The $\mathrm{Na}$ content $[\mathrm{Na} /(\mathrm{Na}+\mathrm{K}+\mathrm{Ca})]$ of the lower- $P$ eclogite-facies muscovite ranges from 0.12 to 0.14 and the $\mathrm{K}$ content in coexisting paragonite is 0.05 . The gap is consistent with the experimental compositional limits of the muscovite - paragonite solvus defined by Roux and Hovis (1996) (Fig. 5) and with data on naturally oc- 


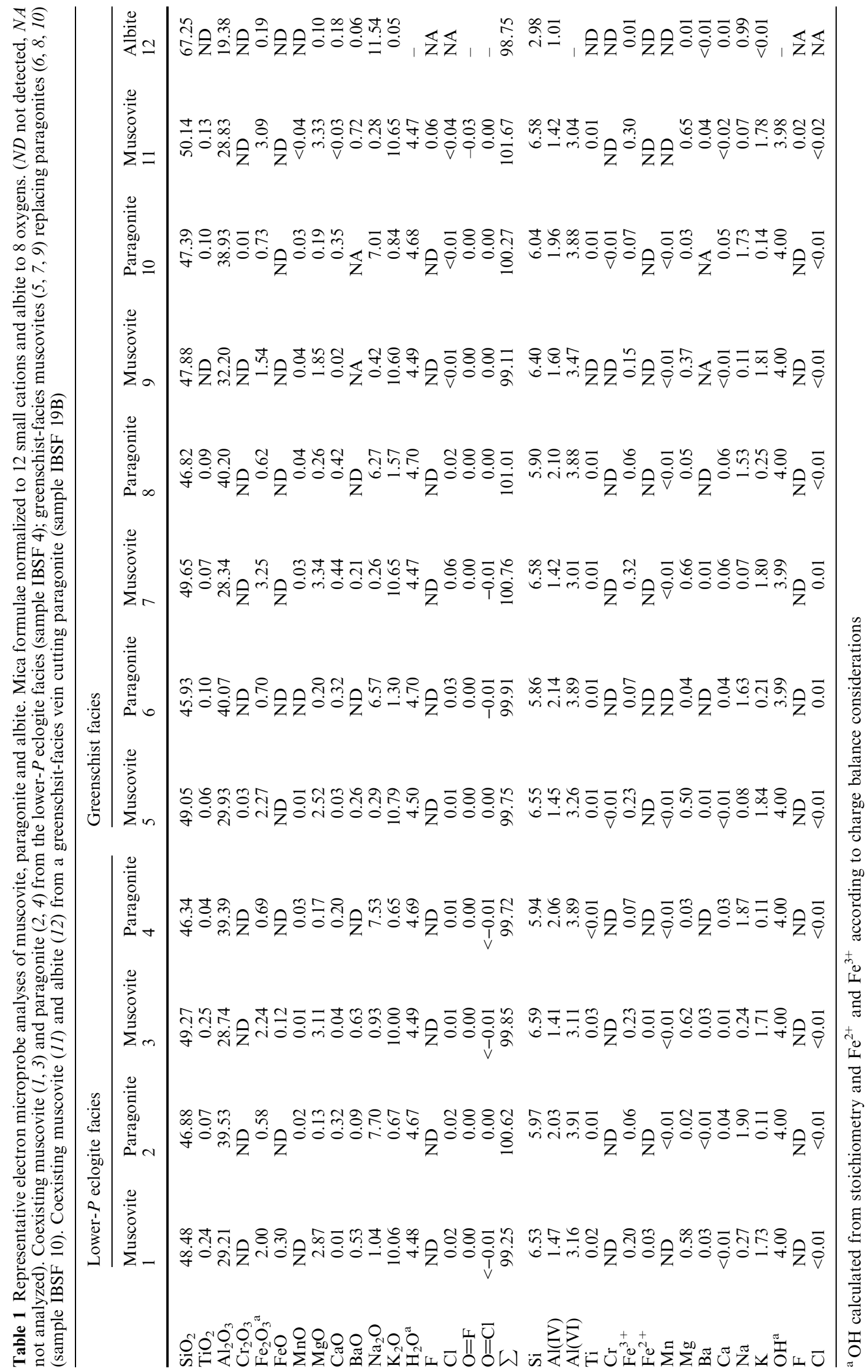






Fig. 5 Comparison between some paragonites and muscovites from the lower- $P$ eclogite-facies assemblage and the solvi calculated at 2, 6, and 15 kbar (Roux and Hovis 1996). Dotted and dash areas represent different mean $X_{\mathrm{Ms}}$ values on paragonite and muscovite coexisting, at equilibrium, in two separated areas of the same thin section. The width of the boxes corresponds to the $2 \sigma$ of the mean $X_{\mathrm{Ms}}$ values. The estimated temperatures and pressures for the lower- $P$ eclogite facies are 500-600 ${ }^{\circ} \mathrm{C}$ and 16-19 kbar. The dark-grey area represents the $X_{\mathrm{Ms}}$ values of muscovite from the greenschist-facies assemblage (estimated temperature and pressure: ca. $300{ }^{\circ} \mathrm{C}$ and $4-7$ kbar)

curring samples (Guidotti et al. 1994) for equilibrium conditions. The low Na content in the greenschist-facies muscovite and the high $\mathrm{K}$ content in the lower- $P$ eclogite-facies paragonite implies disequilibrium replacement (Guidotti et al. 1994). The phengite contents in the lower- $P$ eclogite-facies muscovite and the greenschistfacies muscovite are comparable. No F and very little $\mathrm{Cl}$ were detected in the micas. The paragonite has minor $\mathrm{Ca}$, and the greenschist-facies muscovite has significant levels of $\mathrm{Ba}(0.7-0.8 \mathrm{wt} \% \mathrm{BaO})$. The feldspar in the muscovite - albite veins is nearly pure albite $\left(\mathrm{Ab}_{98.4^{-}}\right.$ $\left.\mathrm{An}_{1.3} \mathrm{Or}_{0.2-0.4}\right)$.

Representative formulae of lower- $P$ eclogite-facies paragonite and greenschist-facies muscovite obtained from AEM analyses are shown in Table 2. All analyses but one were obtained in areas where both SAED patterns and lattice-fringe images showed a single phase. The mixed analysis is from an area where the two micas form parallel intergrowths. Paragonite has lower Si and higher Al contents (Si range: 5.98-6.03 pfu) than muscovite (Si range: 6.29-6.35 pfu). Muscovite also has higher $\mathrm{Mg}$ and $\mathrm{Fe}$ contents. Paragonite always contains small amounts of $\mathrm{K}(0.17-0.20 \mathrm{pfu})$ and $\mathrm{Ca}(0.08-0.19$ pfu) leading to a variation in the $\mathrm{K} /(\mathrm{K}+\mathrm{Na}+\mathrm{Ca})$ ratio from 0.07 to 0.09 . On the other hand, AEM analyses of muscovite show no $\mathrm{Na}$ or $\mathrm{Ca}$. Figure 6 is a $\mathrm{K} /$ $(\mathrm{K}+\mathrm{Na}+\mathrm{Ca})$ versus $\mathrm{Si}$ diagram and shows that the compositions obtained by AEM are comparable to the compositions obtained from electron microprobe analyses, within the limits of precision of the methods.

\section{TEM observations of the coexisting micas}

TEM characteristics of single micas

Muscovite and paragonite were identified through their characteristic 001 diffraction patterns, lattice-fringe images, and AEM analyses. Lower- $P$ eclogite-facies paragonite occurs in $100 \AA$-thick homogeneous packets of layers (Fig. 7a). Selected area electron diffraction (SAED) patterns always indicate a two-layer polytype $\left(2 \mathrm{M}_{1}\right)$, with sharp diffraction spots and no streaking along c* (Fig. 7b). Paragonite is highly unstable under the electron beam and displays the typical "mottled" texture caused by alkali diffusion (Ahn et al. 1986). During observations, lenticular voids (i.e., splitting of layers) form in paragonite and increase progressively in size, confirming their origin through beam damage (Fig. 8).

Muscovite that is intergrown with paragonite is easily distinguished by its different image contrast and its greater stability under the electron beam. Two-dimensional lattice-fringe images are easier to obtain in muscovite and no lenticular voids form in it during TEM observation (Fig. 9). The SAED patterns of 100 A-thick muscovite packets indicate a $2 \mathrm{M}_{1}$ polytype.
Table 2 Representative AEM analyses of white micas. Mica formulae normalized on the basis of 12 total tetrahedral and octahedral cations. All Fe as ferrous iron

\begin{tabular}{lccccccc}
\hline & Muscovite & Muscovite & Muscovite & Paragonite & Paragonite & Paragonite & $\begin{array}{c}\text { Paragonite }+ \\
\text { Muscovite }\end{array}$ \\
\hline $\mathrm{Si}$ & 6.29 & 6.32 & 6.35 & 6.03 & 6.01 & 5.98 & 6.06 \\
$\mathrm{Al}(\mathrm{IV})$ & 1.71 & 1.68 & 1.65 & 1.97 & 1.99 & 2.02 & 1.94 \\
$\mathrm{Al}(\mathrm{VI})$ & 3.03 & 3.07 & 2.85 & 3.82 & 3.79 & 3.55 & 3.29 \\
$\mathrm{Ti}$ & 0.00 & 0.00 & 0.08 & 0.00 & 0.00 & 0.00 & 0.00 \\
$\mathrm{Fe}^{2+}$ & 0.64 & 0.45 & 0.54 & 0.18 & 0.21 & 0.45 & 0.37 \\
$\mathrm{Mg}$ & 0.33 & 0.38 & 0.52 & 0.00 & 0.00 & 0.00 & 0.34 \\
$\mathrm{Mn}$ & 0.00 & 0.09 & 0.00 & 0.00 & 0.00 & 0.00 & 0.00 \\
$\mathrm{Na}$ & 0.00 & 0.00 & 0.00 & 2.11 & 1.85 & 1.85 & 0.56 \\
$\mathrm{Ca}$ & 0.00 & 0.00 & 0.00 & 0.08 & 0.08 & 0.19 & 0.00 \\
$\mathrm{~K}$ & 1.69 & 1.86 & 2.05 & 0.17 & 0.20 & 0.18 & 1.55 \\
$\mathrm{Tot}$ & 13.69 & 13.86 & 14.05 & 14.36 & 14.13 & 14.21 & 14.12 \\
$\mathrm{~K} /(\mathrm{K}+\mathrm{Na}$ & 1 & 1 & 1 & 0.07 & 0.09 & 0.08 & 0.73 \\
$\quad+\mathrm{Ca})$ & & & & & & & \\
\hline
\end{tabular}




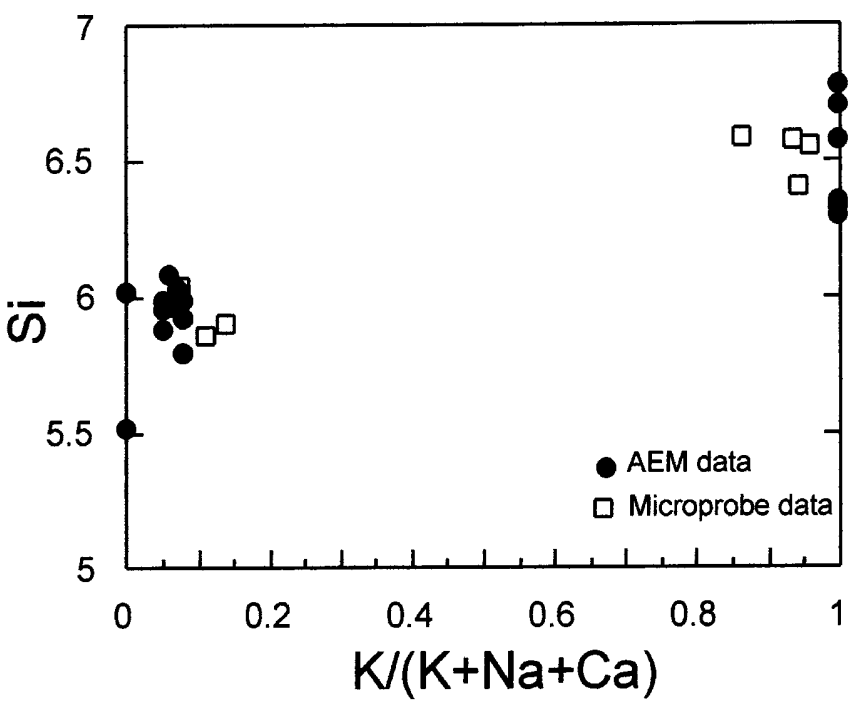

Fig. 6 Plot of $\mathrm{K} /(\mathrm{K}+\mathrm{Na}+\mathrm{Ca})-\mathrm{Si}$ data for muscovite and paragonite. Data from AEM (dots) and electron microprobe (squares) analyses. High K content in muscovite corresponds to substitution of a large celadonite component. Note that AEM and probe analyses are in good agreement with the microprobe data

Figure 10a shows a c*-b* diffraction pattern of muscovite with streaking along $0 \mathrm{kl}$ reciprocal lattice rows with $k \neq 3 n$. Diffuse satellite reflections can also be observed and they indicate semi-random layer-stacking sequences. The corresponding lattice-fringe image (Fig. 10b) displays non-periodic stacking faults along c. The stacking sequence appears to be semi-random and cannot be related to a specific polytype. This kind of stacking disorder is common to that seen in other phyllosilicates

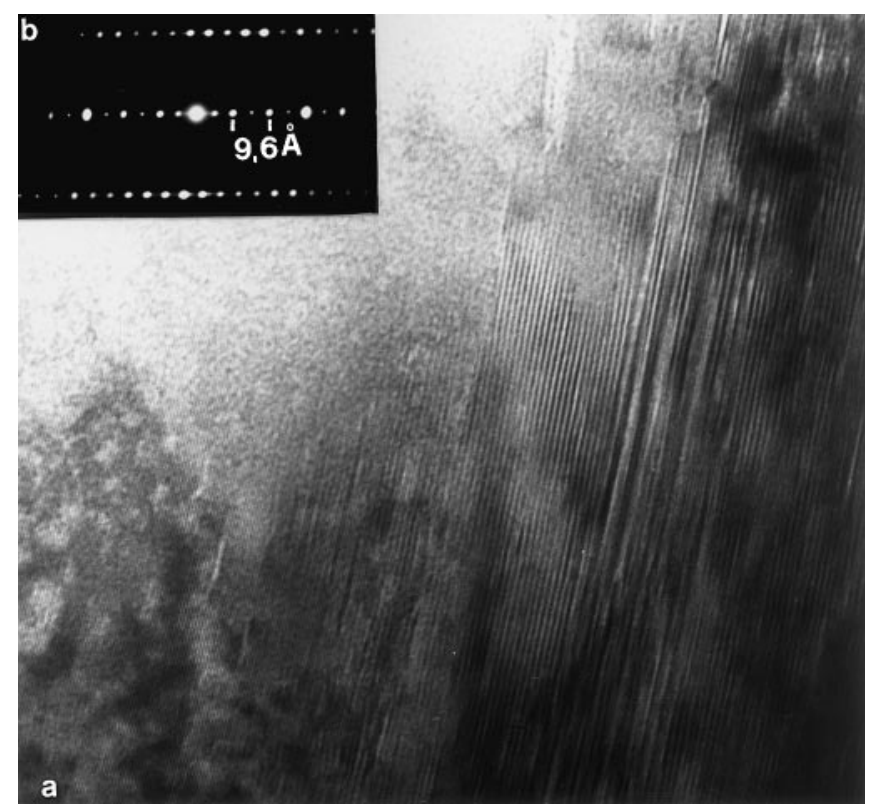

Fig. 7 a Lattice-fringe image of homogeneous packets of lower- $P$ eclogite-facies paragonite showing 9.6 and $19.2 \AA$ - periodicities. b The corresponding electron diffraction pattern $\left(\mathrm{c}^{*}-\mathrm{b}^{*}\right)$ to a Paragonite is a $2 \mathrm{M}$ - polytype with no streaking along 0kl rows (sample IBSF 10)

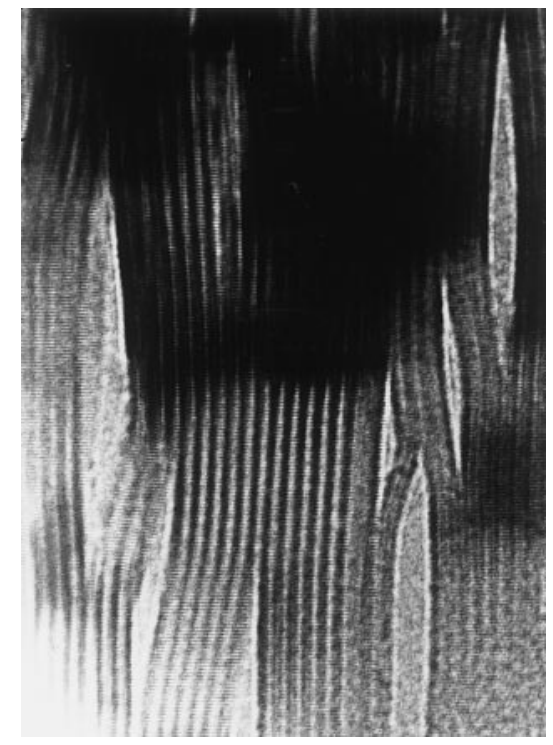

Fig. 8 Lattice-fringe image of lower- $P$ eclogite-facies paragonite displaying lenticular voids due to beam damage (sample IBSF 10)

such as biotite and chlorite (Iijima and Zhu 1982; Veblen 1983; Spinnler et al. 1984) but is unusual in muscovite. Ahn et al. (1985) observed streaking along c* in both paragonite and phengite as a result of random layer rotations of $n\left(120^{\circ}\right)$ around c.

Textural relations between muscovite and paragonite

The typical textural relation between the greenschistfacies muscovite and the lower- $P$ eclogite-facies paragonite is shown by SAED and its corresponding lattice-fringe image (Fig. 11). As the beam was moved from muscovite towards paragonite, the SAED pattern

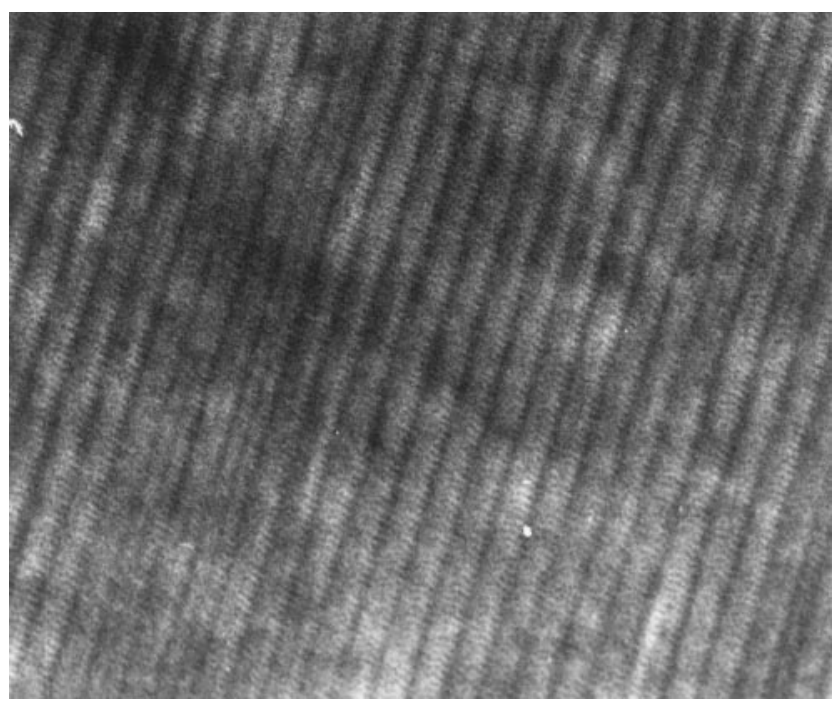

Fig. 9 Lattice-fringe images of greenschist-facies muscovite intergrown with paragonite (sample IBSF 10) 


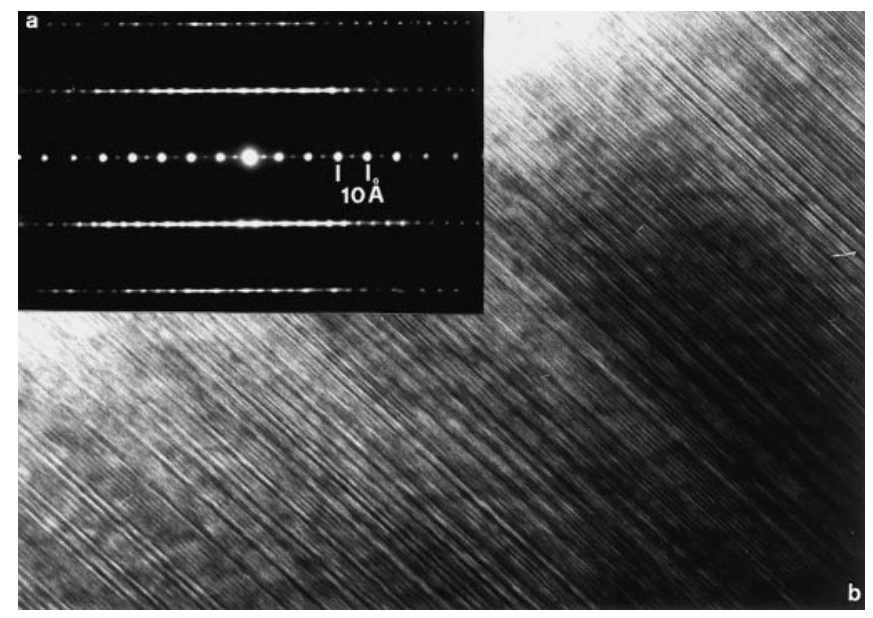

Fig. 10 a Electron diffraction pattern of greenschist-facies muscovite $\left(2 \mathrm{M}_{1}\right.$ polytype $)$ with streaking along $0 \mathrm{kl}$ reciprocal lattice rows with $k \neq 3 n$. b Corresponding lattice-fringe image of muscovite with nonperiodic stacking faults along c (sample IBSF 10)

periodicity along c* changed from 10 to $9.6 \AA$. Figure 11a shows the diffraction pattern obtained at the muscovite - paragonite boundary itself. The boundary cuts obliquely across (001) layers (Fig. 11b). The 001 fringes appear to be continuous in most cases across the boundary, which implies strict coherency between the

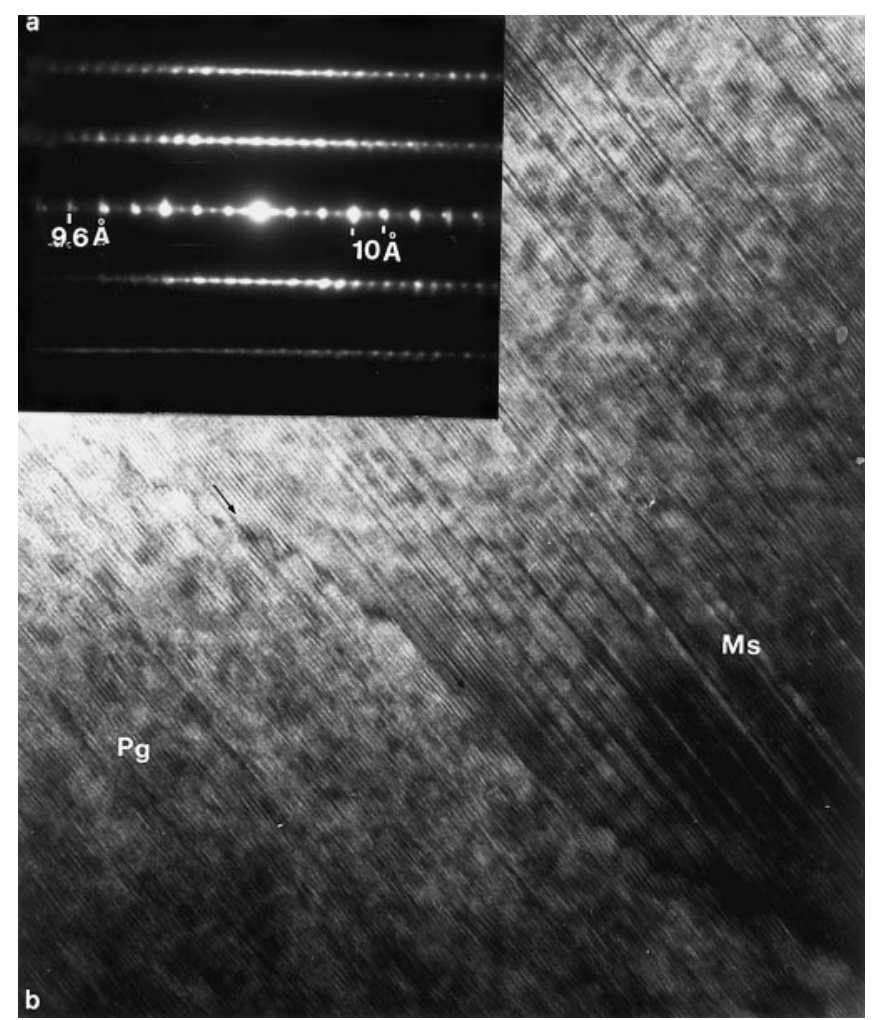

Fig. 11 a Electron diffraction pattern of greenschist-facies muscovite replacing lower- $P$ eclogite-facies paragonite, showing splitting of the 001 reflections along $c^{*}$. b Corresponding lattice-fringe image. The interface between the two micas ( $P g$ paragonite, $M s$ muscovite) is oblique with respect to basal planes (arrow) (sample IBSF 10) two micas. Such oblique boundaries are generally rare between phyllosilicates, and almost all observed boundaries are parallel to (001). In our case, the boundary is marked by the presence of strain contrast among the layers and by frequent layer terminations. The $\mathrm{c}^{*}$ directions of the two micas are perfectly parallel, but the $a^{*}$ and $b^{*}$ directions show some differences in orientations. This is consistent with the observations that the 001 fringes are largely coherent across the boundaries. No periodicities between 10 and $9.6 \AA$ were observed, which indicates that muscovite and paragonite layers are close to end-member compositions.

\section{Discussion}

The data described above define a complex sequence of multi-stage assemblages that include paragonite \pm muscovite of more than one origin (Tropper 1998, Fig. 12). The textural and compositional data for mus-

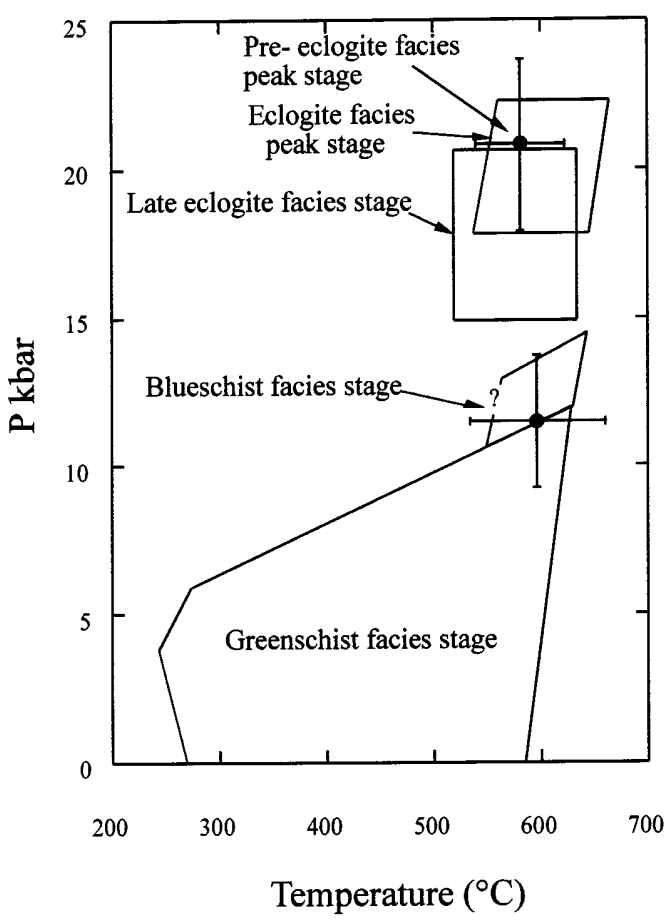

Fig. 12 Peak conditions and retrograde $P-T$ path of the eclogites from the Sesia-Lanzo Zone. The data were obtained by calculating invariant points in the system NCFMASH with the data base of Holland and Powell (1990) and their software THERMOCALC v 2.4 (T.J.B. Holland personal communication 1995). The invariant points, calculated for the pre-high-pressure peak conditions and the blueschist-facies conditions also include the $2 \sigma$ errors. The $P-T$ box of the eclogite facies is based on the upper and lower limits of garnet omphacite thermometry and invariant points from 5 samples among the phases garnet + omphacite + kyanite + clinozoisite + quartz. The $P-T$ box of the lower- $P$ eclogite facies is based on the upper and lower limits of garnet - omphacite and garnet - hornblende thermometry and invariant points from 4 samples among the phases garnet + omphacite + clinozoisite + quartz. The $P-T$ field of the greenschist facies is constrained by limiting reactions among the phases glaucophane + clinozoisite + linochlore + tremolite + albite + prehnite + pumpellyite + quartz 
covite and paragonite, as interpreted in terms of that $P-T$ path, define both equilibrium relations for lower- $P$ eclogite-facies assemblages, and non-equilibrium relations for greenschist-facies assemblages.

\section{Chemical constraints on equilibrium relations}

Despite repeated experimental investigations on the muscovite-paragonite solvus (e.g., Eugster and Yoder 1955; Eugster et al. 1972; Chatterjee and Flux 1986; Roux and Hovis 1996) discrepancies still exist between natural and experimental results. Additional components in muscovite and paragonite are potential sources of uncertainties. Such substitutions may perturb the $\mathrm{Na}$ and $\mathrm{K}$ partitioning between muscovite and paragonite (Guidotti and Sassi 1998). The solvus is widened with increasing celadonite substitution (Guidotti 1984; Ahn et al. 1985; Blencoe et al. 1994; Guidotti et al. 1994; Roux and Hovis 1996).

Paragonites from the lower- $P$ eclogite-facies assemblage contain up to $10 \%$ muscovite component $\left(X_{\mathrm{Ms}}\right)$. This is consistent with the compositional limits of the muscovite - paragonite solvus by Roux and Hovis (1996) for these conditions $\left(500-600{ }^{\circ} \mathrm{C} ; 16-19 \mathrm{kbar}\right)$ (Fig. 5). According to their solvus, the muscovite content $\left(X_{\mathrm{Ms}}\right)$ in the equilibrated muscovite should be $75-85 \%$. This is indeed the range of composition of muscovite from the lower- $P$ eclogite-facies assemblage (see Table 1 ), which is in apparent textural equilibrium with paragonite.

Another component which causes a widening of the limbs of the solvus is the margarite-component substitution in paragonite (Zen and Albee 1964). A similar effect may be anticipated for the preferential substitution of $\mathrm{Ba}$ in muscovite. However, muscovite and paragonite from all the assemblages have negligible $\mathrm{Ca}$ and $\mathrm{Ba}$ contents. Among the potential sources of uncertainties are the presence of a metastable chemically homogeneous Na-K mica (Jiang and Peacor 1993) and submicroscopic muscovite-paragonite intergrowths (Ahn et al. 1985; Shau et al. 1991; Boundy et al. 1997; Giorgetti et al. 1997).

Electron microprobe and AEM analyses of muscovite from the greenschist facies show that muscovite is almost Na-free even though it occurs immediately adjacent to lower- $P$ eclogite-facies paragonite (Table 1). The $100 \mathrm{~K} /(\mathrm{K}+\mathrm{Na})$ component in the greenschist-facies muscovite, as determined from electron microprobe analysis, is $90 \%$, but it is probably due to contamination by paragonite layers too small to be resolved by the electron beam. Considering the solvus characteristics and possible effects of extra components in muscovite, its composition indicates that it is not in equilibrium with paragonite from the lower- $P$ eclogite facies (Fig. 5). Moreover, the greenschist-facies muscovite has a much smaller content of $\mathrm{Na}$ than one would expect in a paragonite-saturated system.

Possible muscovite-forming reactions in the greenschist facies are:
$\mathrm{NaAl}_{3} \mathrm{Si}_{3} \mathrm{O}_{10}(\mathrm{OH})_{2}+\mathrm{K}^{+}=\mathrm{KAl}_{3} \mathrm{Si}_{3} \mathrm{O}_{10}(\mathrm{OH})_{2}+\mathrm{Na}^{+}$

$\mathrm{NaAl}_{3} \mathrm{Si}_{3} \mathrm{O}_{10}(\mathrm{OH})_{2}+6 \mathrm{SiO}_{2}+2 \mathrm{Na}^{+}=3 \mathrm{NaAlSi}_{3} \mathrm{O}_{8}+2 \mathrm{H}^{+}$

Combination of the two reactions leads to the formation of albite - muscovite from quartz - paragonite. Some samples show albite - muscovite pseudomorphs after paragonite (Fig. 13), suggesting progression of reactions (1) and (2) to the right. The vein assemblage muscovite albite invites application of the plagioclase-muscovite exchange thermometer (Green and Usdansky 1986, 1989). The result for the analyses reported in Table 1 is $300 \pm 30^{\circ} \mathrm{C}$ for $5 \pm 2 \mathrm{kbar}$ and for Or varying from 0.2 to $0.6 \mathrm{~mol} \%$. Although the results seem reasonable, the equations provided in an erratum (Green and Usdansky 1989) do not reproduce the values of Green and Usdansky (1986) in their Table 2: systematic descrepancies of -4 to $-50{ }^{\circ} \mathrm{C}$ are incurred. Nonetheless, the $300{ }^{\circ} \mathrm{C}$ temperature estimate is at the lower end of the range obtained for the greenschist facies by Tropper (1998).

\section{Textural constraints on equilibrium relations}

The BSE and TEM images show that the two white mica domains have interfaces obliquely transecting their basal planes. Similar textural relations have been documented only rarely for micas (Livi et al. 1988, 1997; Jiang and Peacor 1993). Jiang and Peacor (1993) proposed that this texture formed through alkali exchange and diffusion as opposed to dissolution and neocrystallization. The latter process would have formed lamellar intergrowths of parallel muscovite and paragonite packets, which are absent in our study. The micas described by Jiang and Peacor owe their textures and compositions to high- $T$ hydrothermal processes at the contact between shale and mafic dikes. Their TEM observations suggest

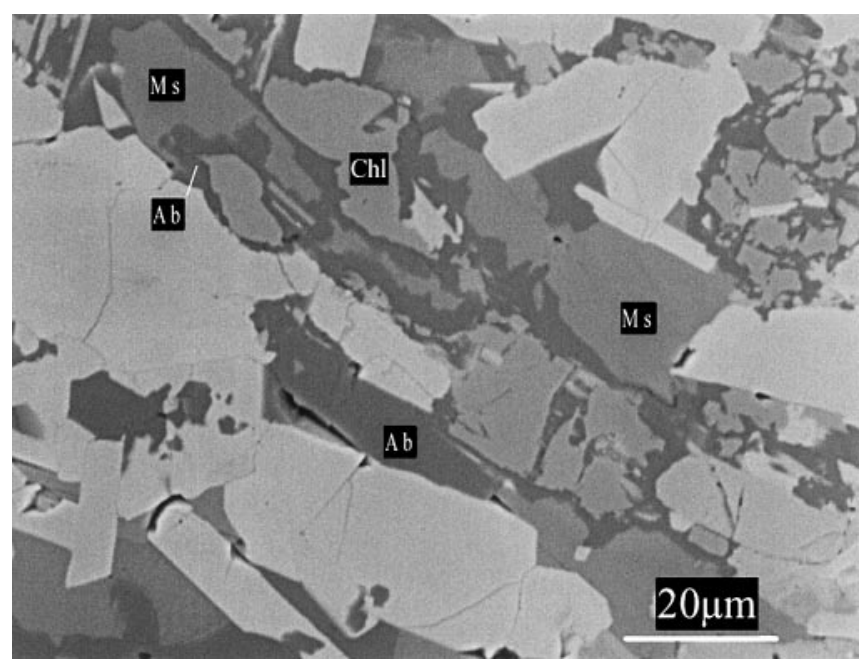

Fig. 13 BSE image showing greenschist-facies albite $(A b)$ - muscovite $(M s)$ pseudomorph after paragonite (sample IBSF 19B); the scale bar is $10 \mu \mathrm{m}$ 
that the two micas grew under non-equilibrium conditions. Livi et al. $(1988,1997)$ studied white micas from low-grade metamorphosed Liassic shales. They reported images of oblique contacts between paragonite and muscovite and described Na- and K-rich micas as domains and not as intercalations. These authors implied that the inclined compositional boundaries represent exsolution based on similarities in texture with those of Na-biotite and talc that were exsolved from wonesite (Veblen 1983). Nonetheless, the TEM images and corresponding SAED patterns of interlayered muscovite and paragonite which they presented are not conclusive evidence for a modulated structure. The two phases are always present as shown by their characteristic diffraction effects; no modulated microstructures are visible, and no satellite reflections at right angles to the modulation appear in the SAED pattern.

The textural relations observed in the present study imply that at least most paragonite and muscovite layers are coherent across boundaries, although the boundaries are marked by a substantial concentration of layer terminations. Furthermore, there are significant differences in the compositions of the octahedral and tetrahedral sites of the two micas. The compositions change abruptly at the boundaries without a gradual variation towards the muscovite - paragonite interface, and with no intermediate, homogeneous $\mathrm{Na}-\mathrm{K}$ phase being found. At temperatures below $400{ }^{\circ} \mathrm{C}$, micas become closed systems for alkali exchange by volume diffusion (Fortier and Giletti 1991, and references therein). In a $100 \mu \mathrm{m}$ mica grain, at $400{ }^{\circ} \mathrm{C}$ after $1 \mathrm{Ma}, \mathrm{K}$ can diffuse for about $50 \%$, after $0.1 \mathrm{Ma}$ there is no exchange, and after $10 \mathrm{Ma}, \mathrm{K}$ can completely diffuse from one mineral to another (Crank 1975; ZD Sharp 1999, personal communication). In a wide range of pressure and temperature, transport of large alkali cations within the mica structure is sluggish, and large changes in the octahedral and tetrahedral layers require a dissolutiontransport-precipitation reaction mechanism (Schramke et al. 1987). Moreover, textural evidence such as complex textures, different mineral compositions and assemblages from different facies, strongly indicates limited diffusion and dissolution-reprecipitation in general. This process is driven by the presence of an aqueous fluid which promotes the replacement of individual paragonite layers by muscovite. The similar layered structures of the two micas cause the process to occur along the basal planes as commonly observed for transitions between layer silicates, generating partial coherency through the interfaces.

Acknowledgments This study was supported by NSF grants EAR 95-26956, EAR 94-18108, and MURST-COFIN '98 to C.A. Ricci. Guido Venturini and Giovanni Armando are thanked for their valuable help in the field. Li-Shun Kao and Pilar Mata are thanked for their help on the TEM, Gejing Li for her assistance with sample preparation, Carl Henderson for his guidance in the Electron Microbeam Analytical Laboratory of the University of Michigan. Christoph Hauzenberger is thanked for his help with the SEM at the Institut für Mineralogie-Kristallographie und Petrologie at the Karl-Franzens Universität Graz.

\section{References}

Afifi A, Essene EJ (1988) MINFILE, a microcomputer program for storage and manipulation of chemical data on minerals. Am Mineral 73: 446-448

Ahn JH, Essene EJ, Peacor DR (1985) Coexisting paragonitephengite in blueschist eclogite: a TEM study. Am Mineral 70: 1193-1204

Ahn JH, Peacor DR, Essene EJ (1986) Cation-diffusion-induced characteristic beam damage in transmission electron microscope images of micas. Ultramicroscopy 19: 375-382

Armando G (1992) Studio geologico dell'alta valle dell'Elvo (Zona Sesia-Lanzo, Alpi Occidentali). MSc thesis, Univ Torino

Blencoe JG, Guidotti CV, Sassi FP (1994) The paragonite-muscovite solvus. II. Numerical geothermometers for natural, quasibinary paragonite-muscovite pairs. Geochim Cosmochim Acta 58: 2277-2288

Boundy TM, Hall CM, Li G, Essene EJ, Halliday AN (1997) Finescale isotopic heterogeneities and fluids in the deep crust: a ${ }^{40} \mathrm{Ar} /{ }^{39} \mathrm{Ar}$ laser ablation and TEM study of muscovites from a granulite-eclogite transition zone. Earth Planet Sci Lett 148: 223-242

Chatterjee ND, Flux S (1986) Thermodynamic mixing properties of muscovite-paragonite solutions at high temperatures and pressures, and their geological applications. J Petrol 27: 677-693

Compagnoni R, Dal Piaz GV, Hunziker JC, Gosso G, Lombardo B, Williams PF (1977) The Sesia-Lanzo Zone, a slice of continental crust with Alpine high pressure-low temperature assemblages in the western Italian Alps. Rend Soc Ital Mineral Petrol 33: 281-334

Crank J (1975) The mathematics of diffusion. Clarendon Press, Oxford

Dal Piaz GV, Hunziker JC, Martinotti G (1972) La Zona SesiaLanzo e l'evoluzione tectonico-metamorphica delle Alpi nord occidentali interne. Mem Soc Geol Ital 11: 433-466

Droop GTR, Lombardo B, Pognante U (1990) Formation and distribution of eclogite-facies rocks in the Alps. In: Carswell DA (ed) Eclogite-facies rocks, Blackie, Glasgow, pp 225-259

Essene EJ (1982) Geologic thermometry and barometry. In: Ferry JM (ed) Characterization of metamorphism through mineral equilibria. (Reviews in mineralogy, 10) Mineral Soc Am, Washington, DC, pp 153-206

Eugster HP, Yoder HS (1955) The join muscovite - paragonite. Annu Rep Geophys Lab 54: 124-126

Eugster HP, Albee AL, Bence AE, Thompson JB, Waldbaum DR (1972) The two phase region and excess mixing properties of paragonite - muscovite crystalline solutions. J Petrol 13: 147179

Flux S, Chatterjee ND (1986) Experimental reversal of the Na-K exchange reaction between muscovite-paragonite crystalline solutions and a 2 molal aqueous $(\mathrm{Na}, \mathrm{K}) \mathrm{Cl}$ fluid. J Petrol 27: 665-676

Fortier SM, Giletti BJ (1991) Volume self-diffusion of oxygen in biotite, muscovite, and phlogopite micas. Geochim Cosmochim Acta 55: 1319-1330

Frey M (1969) A mixed-layer paragonite/phengite of low-grade metamorphic origin. Contrib Mineral Petrol 24: 63-65

Giorgetti G, Memmi I, Nieto F (1997) Microstructures of intergrown phyllosilicate grains from Verrucano metasediments (northern Apennines, Italy). Contrib Mineral Petrol 128: 127138

Graham CM, Powell R (1984) A garnet-hornblende geothermometer: calibration, testing, and application to the Pelona Schist, Southern California. J Metamorphic Geol 2: 13-31

Green NL, Usdansky SI (1986) Toward a practical plagioclasemuscovite thermometer. Am Mineral 71: 1109-1117

Green NL, Usdansky SI (1989) Erratum. Am Mineral 74: 505

Guidotti CV (1984) Micas in metamorphic rocks. In: Bailey SW (ed) Micas. (Reviews in mineralogy, 13) Mineral Soc Am, Washington, DC, pp 357-467 
Guidotti CV, Sassi FP, Blencoe JG, Selverstone J (1994) The paragonite-muscovite solvus. I. $P-T-X$ limits derived from the $\mathrm{Na}-\mathrm{K}$ compositions of natural, quasibinary paragonite-muscovite pairs. Geochim Cosmochim Acta 58: 2269-2275

Guidotti CV, Sassi FP (1998) Petrogenetic significance of Na-K white mica mineralogy: recent advances for metamorphic rocks. Eur J Mineral 10: 815-854

Holland TJB, Powell R (1990) An enlarged and updated internally consistent thermodynamic dataset with uncertainties and correlations: the system $\mathrm{K}_{2} \mathrm{O}-\mathrm{Na}_{2} \mathrm{O}-\mathrm{CaO}-\mathrm{MgO}-\mathrm{MnO}-$ $\mathrm{Fe}_{2} \mathrm{O}_{3}-\mathrm{Al}_{2} \mathrm{O}_{3}-\mathrm{TiO}_{2}-\mathrm{SiO}_{2}-\mathrm{C}-\mathrm{H}_{2}-\mathrm{O}_{2}$. J Metamorphic Geol 8: 89-124

Iijima S, Zhu J (1982) Electron microscopy of a muscovite - biotite interface. Am Mineral 67: 1195-1205

Jiang WT, Peacor DR (1993) Formation and modification of metastable intermediate sodium potassium mica, paragonite, and muscovite in hydrothermally altered metabasalts from northern Wales. Am Mineral 78: 782-793

Krogh EJ (1988) The garnet-clinopyroxene Fe-Mg geothermometer - a reinterpretation of existing experimental data. Contrib Mineral Petrol 99: 44-48

Lardeaux JM, Gosso G, Kienast JR, Lombardo B (1982) Relations entre le métamorphisme et la déformation dans la zone de Sésia-Lanzo (Alpes occidentales) et le probléme de l'éclogitisation de la croute continentale. Bull Soc Geol Fr 24: 793-800

Li G, Peacor DR, Merriman RJ, Roberts B (1994a) The diagenetic to low-grade metamorphic evolution of matrix white micas in the system muscovite-paragonite in a mudrock from central Wales, United Kingdom. Clays Clay Miner 42: 369-381

Li G, Peacor DR, Merriman RJ, Roberts B, van der Pluijm BA (1994b) TEM and AEM constraints on the origin and significance of chlorite-mica stacks in slates: an example from central Wales, UK. J Struct Geol 16: 1139-1157

Livi KJT, Veblen DR, Ferry JM (1988) Electron microscope study of anchizone and epizone metamorphosed shales from the central Swiss Alps (abstract). Geol Soc Am Abstr Program 20: A244

Livi KJT, Veblen DR, Ferry JM, Frey M (1997) Evolution of 2:1 layered silicates in low-grade metamorphosed Liassic shales of central Switzerland. J Metamorphic Geol 15: 323-344

Morten L (1993) Italian eclogites and related rocks. Accad Naz Sci Detta Dei XL, Roma
Mottana A, Carswell DA, Chopin C, Oberhänsli R (1990) Eclogitefacies mineral paragenesis. In: Carswell DA (ed) Eclogite-facies rocks, Blackie, Glasgow, pp 14-52

Paschier CW, Urai JL, Van Loon J, Williams PF (1981) Structural geology of central Sesia-Lanzo Zone. Geol Mijnbouw 60: 497507

Reinsch D (1979) Glaucophanites and eclogites from Val Chiusella, Sesia-Lanzo Zone (Italian Alps). Contrib Mineral Petrol 70: 257-266

Rosenfeld JL, Thompson JB, Zen E (1958) Data on coexisting muscovite and paragonite. Geol Soc Am Bull 69: 1637

Roux J, Hovis GL (1996) Thermodynamic mixing models for muscovite - paragonite solutions based on solution calorimetric and phase equilibrium data. J Petrol 37: 1241-1254

Rubie DC (1984) A thermal-tectonic model for high pressure metamorphism and deformation in the Sesia Zone, Western Alps. J Geol 92: 21-36

Schramke JA, Kerrick DM, Lasaga AC (1987) The reaction muscovite + quartz $=$ andalusite $+\mathrm{K}$-feldspar + water. 1 . Growth kinetics and mechanism. Am J Sci 287: 517-559

Shau YH, Feather ME, Essene EJ, Peacor DR (1991) Genesis and solvus relations of submicroscopically intergrown paragonite and phengite in a blueschist from northern California. Contrib Mineral Petrol 106: 367-378

Spinnler GE, Self PG, Iijima S, Buseck PR (1984) Stacking disorder in clinochlore chlorite. Am Mineral 69: 252-263

Tropper P (1998) Experimental and field-related investigations on the metamorphic history of eclogites in the Sesia-Lanzo Zone, Western Alps (Italy). PhD thesis, Univ Michigan

Veblen DR (1983) Microstructures and mixed layering in intergrown wonesite, chlorite, talc, biotite and kaolinite. Am Mineral 68: $566-580$

Venturini G (1995) Geology, geochemistry and geochronology of the inner central Sesia Zone (Western Alps - Italy). Mem Geol 25

Venturini G, Martinotti G, Armando G, Barbero M, Hunziker JC (1994) The Central Sesia-Lanzo Zone (Western Italian Alps): new field observations and lithostratigraphic subdivisions. Schweiz Mineral Petrogr Mitt 74: 111-121

Zen E-An, Albee AL (1964) Coexistent muscovite and paragonite in pelitic schist. Am Mineral 49: 904-925 